\title{
A Process for Assessment of ABET Student Outcomes in a Mechanical Engineering Department
}

\author{
Risa Robinson, Ph.D. ${ }^{1}$, and Edward Hensel Jr., PhD. ${ }^{1}$ \\ ${ }^{1}$ Rochester Institute of Technology, Rochester, NY, USA, rjreme@rit.edu, hensele@asme.org
}

\begin{abstract}
A formal three-point student outcomes assessment process has been implemented in the Mechanical Engineering (ME) department at Rochester Institute of Technology. The process was established in academic year 2012. The ME program defined highlevel performance indicators associated with each of the eleven ABET student outcomes (a)-(k). Required ME courses were mapped to performance criteria by 1 of 4 instructional strategy levels, where 1 represents the lowest level of rigor and 4 represent the highest level of rigor. Achievement of student outcomes is carried out by summing student performance first across all courses contributing to a given PI, then by all PIs contributing to a given outcome. Performance is gauged against an achievement benchmark as well as a saturation benchmark, the latter is meant to indicate the potential need to increase rigor in a given area. The student outcomes assessment process involves not only evaluating student performance, but also evaluating the appropriateness of the program level instructional strategy to prepare students to meet the outcome and the data sources as an appropriate measure of outcome achievement.
\end{abstract}

Keywords- Assessment, Continuous Improvement

Digital Object Identifier (DOI): http://dx.doi.org/10.18687/LACCEI2015.1.1.262

ISBN: 13 978-0-9822896-8-6

ISSN: 2414-6668

13 ${ }^{\text {th }}$ LACCEI Annual International Conference: “Engineering Education Facing the Grand Challenges, What Are We Doing?” July 29-31, 2015, Santo Domingo, Dominican Republic ISBN: 13 978-0-9822896-8-6

ISSN: 2414-6668

DOI: http://dx.doi.org/10.18687/LACCEI2015.1.1.262 


\title{
A Process for Assessment of ABET Student Outcomes in a Mechanical Engineering Department
}

\author{
Risa Robinson ${ }^{1}$, Ph.D., Edward Hensel Jr. ${ }^{1}$, Ph.D. \\ ${ }^{1}$ Rochester Institute of Technology, Rochester, NY, USA, rjreme@ rit.edu, hensele@asme.org
}

\begin{abstract}
A formal three-point student outcomes assessment process has been implemented in the Mechanical Engineering (ME) department at Rochester Institute of Technology. The process was established in academic year 2012. The ME program defined highlevel performance indicators associated with each of the eleven ABET student outcomes (a)-(k). Required ME courses were mapped to performance criteria by 1 of 4 instructional strategy levels, where 1 represents the lowest level of rigor and 4 represent the highest level of rigor. Achievement of student outcomes is carried out by summing student performance first across all courses contributing to a given PI, then by all PIs contributing to a given outcome. Performance is gauged against an achievement benchmark as well as a saturation benchmark, the latter is meant to indicate the potential need to increase rigor in a given area. The student outcomes assessment process involves not only evaluating student performance, but also evaluating the appropriateness of the program level instructional strategy to prepare students to meet the outcome and the data sources as an appropriate measure of outcome achievement.
\end{abstract}

Keywords: Assessment, Continuous Improvement

\section{INTRODUCTION}

Programs seeking accreditation through the Engineering Accreditation Commission (EAC) of the Accreditation Board for Engineering and Technology (ABET) must "demonstrate that they satisfy all of the following General Criteria for Baccalaureate Level Programs" [1].

1. Students

5. Curriculum

2. Program Educational

6. Faculty

Objectives

7. Facilities

3. Student Outcomes

4. Continuous Improvement

This paper focuses on ABET Criterion 4 - Continuous Improvement, which states:

The program must regularly use appropriate, documented processes for assessing and evaluating the extent to the student outcomes are being attained. The results of these evaluations must be systematically utilized as input for the continuous improvement of the program. Other available information may also be used to assist in the continuous improvement of the program (ABET, 2014).

Assessment of student outcomes in higher education involves both direct and indirect measures of achievement [2]. Direct assessment is the evaluation of student work or performance, for example, exams, reports, presentations [3] [4-7]. Because professional skills are often difficult to assess by course-based measures alone [8], employer-based direct assessment methods have also been used [9, 10]. Indirect assessment is the evaluation of data that would imply achievement without directly observing the student or students work product, for example, student self-assessment, employer focus groups, or retention, graduation and placement rates. Course-based direct assessment is the gold standard on how to directly measure performance [11].

Both direct and indirect assessment requires a significant effort on the part of faculty, and it is often difficult to leverage the data in order to test the impact of curricular innovations over time. This is true at the program level as well as at the course level. In a previous article, the ME program at RIT described a process by which curricular work groups were engaged in course-based direct assessment [12] and how the process was utilized to achieve consistency among courses taught by different instructors. That effort was successful in developing a documented process and this process was utilized at the course level to tack improvements over time at the course level. In the present article, we describe a process that was developed to track improvements at the program level.

\section{STUDENT OUTCOMES}

Student Outcomes (SOs) describe what students are expected to know and be able to do by the time of graduation (skills, knowledge, and behaviours). The ME program has adopted ABET (a) through (k) for their student outcomes as listed in Table I.

TABLE I.

MECHANICAL ENGINEERING STUDENT OUTCOMES

\begin{tabular}{|c|l|l|}
\hline a & $\begin{array}{l}\text { Engineering } \\
\text { Foundations }\end{array}$ & $\begin{array}{l}\text { an ability to apply knowledge of mathematics, } \\
\text { science, and engineering }\end{array}$ \\
\hline b & Experimentation & $\begin{array}{l}\text { an ability to design and conduct experiments, as } \\
\text { well as to analyse and interpret data }\end{array}$ \\
\hline c & Design & $\begin{array}{l}\text { an ability to design a system, component, or } \\
\text { process to meet desired needs within realistic } \\
\text { constraints such as economic, environmental, } \\
\text { social, political, ethical, health and safety, } \\
\text { manufacturability, and sustainability }\end{array}$ \\
\hline d & $\begin{array}{l}\text { Multidisciplinary } \\
\text { Teamwork }\end{array}$ & an ability to function on multidisciplinary teams \\
\hline e & Problem Solving & $\begin{array}{l}\text { an ability to identify, formulate, and solve } \\
\text { engineering problems }\end{array}$ \\
\hline f & $\begin{array}{l}\text { Professional } \\
\text { Responsibility }\end{array}$ & $\begin{array}{l}\text { an understanding of professional and ethical } \\
\text { responsibility }\end{array}$ \\
\hline g & Communication & an ability to communicate effectively \\
\hline h & Broad Education & $\begin{array}{l}\text { the broad education necessary to understand the } \\
\text { impact of engineering solutions in a global, } \\
\text { economic, environmental, and societal context }\end{array}$ \\
\hline i & $\begin{array}{l}\text { Life-long } \\
\text { Learning }\end{array}$ & $\begin{array}{l}\text { a recognition of the need for, and an ability to } \\
\text { engage in life-long learning }\end{array}$ \\
\hline
\end{tabular}




\begin{tabular}{|c|l|l|}
\hline $\mathrm{J}$ & $\begin{array}{l}\text { Contemporary } \\
\text { Issues }\end{array}$ & a knowledge of contemporary issues \\
\hline $\mathrm{k}$ & Modern Tools & $\begin{array}{l}\text { an ability to use the techniques, skills, and } \\
\text { modern engineering tools necessary for } \\
\text { engineering practice }\end{array}$ \\
\hline
\end{tabular}

\section{STUDENT PERFORMANCE INDICATORS}

Each Student Outcome (SO) is associated with two or more performance indicators (PI's) describing the characteristics, skills, knowledge, attitudes, and/or values that students exhibit to demonstrate achievement of the SO. PI's are a means for faculty to articulate the program-specific interpretation of each ABET outcome relative to the $\mathrm{ME}$ program at RIT, and are not additional criteria that students must meet. Achievement of SO's is accomplished by successful demonstration of at least one performance indicator. The list of PIs presented in Table II was informed by learning activities and course learning outcomes of individual courses in the ME program at RIT. It is anticipated that PI's may change over time as part of the continuous improvement process. The assessment system is designed to incorporate changes in PIs without diminishing our ability for longitudinal assessment of $\mathrm{SO}$ achievement.

TABLE II.

ME PROGRAM PERFORMANCE INDICATORS FOR EACH STUDENT OUTCOME

\begin{tabular}{|c|c|c|c|c|}
\hline & & a.1 & Math & $\begin{array}{l}\text { Solve problems involving differential and } \\
\text { integral calculus, linear algebra, and } \\
\text { boundary value equations and statistics. }\end{array}$ \\
\hline $\mathrm{a}$ & $\begin{array}{l}\text { Engin. } \\
\text { Foun. }\end{array}$ & a. 2 & $\begin{array}{l}\text { Engineering } \\
\text { Science }\end{array}$ & $\begin{array}{l}\text { Given a well-defined problem, in the context } \\
\text { of one of the six engineering science courses } \\
\text { (Statics, Strengths, Dynamics, } \\
\text { Thermodynamics, Fluids, Heat) identify the } \\
\text { applicable engineering principle, explain its } \\
\text { appropriateness to the problem, apply } \\
\text { necessary assumptions, conduct the } \\
\text { mathematical analysis and arrive at a } \\
\text { reasonable solution. }\end{array}$ \\
\hline \multirow{3}{*}{ b } & \multirow{3}{*}{ Exper. } & b. 1 & $\begin{array}{l}\text { Design And } \\
\text { Build }\end{array}$ & $\begin{array}{l}\text { Design and build an experimental apparatus } \\
\text { with appropriate measurement tools. }\end{array}$ \\
\hline & & b. 2 & Conduct & $\begin{array}{l}\text { Carry out an experiment, acquire data, } \\
\text { recognize and solve problems with the setup. }\end{array}$ \\
\hline & & b. 3 & Analyse & $\begin{array}{l}\text { Analyse and interpret data, evaluate } \\
\text { uncertainties, and draw conclusions or make } \\
\text { predictions, document results. }\end{array}$ \\
\hline \multirow{5}{*}{$\mathrm{c}$} & \multirow{5}{*}{ Design } & c. 1 & Small Project & and constraints, design a \\
\hline & & c. 2 & $\begin{array}{l}\text { Engineering } \\
\text { Specifications }\end{array}$ & $\begin{array}{l}\text { Define engineering specifications related to a } \\
\text { set of customer needs, realistic constraints } \\
\text { and engineering standards (ASTM, ASME } \\
\text { etc.). }\end{array}$ \\
\hline & & c. 3 & $\begin{array}{l}\text { Design } \\
\text { Concepts }\end{array}$ & $\begin{array}{l}\text { Develop creative design concepts and } \\
\text { evaluate options based on a formal selection } \\
\text { process. }\end{array}$ \\
\hline & & c. 4 & $\begin{array}{l}\text { Functional } \\
\text { Decompositio } \\
\mathrm{n}\end{array}$ & $\begin{array}{l}\text { Convert an ambiguous design concept into } \\
\text { functional systems decomposition and define } \\
\text { the required interfaces to assemble the } \\
\text { system. }\end{array}$ \\
\hline & & c. 5 & $\begin{array}{l}\text { Prototype And } \\
\text { Test }\end{array}$ & $\begin{array}{l}\text { Construct a functional prototype based on } \\
\text { design documentation, and demonstrate }\end{array}$ \\
\hline
\end{tabular}

\begin{tabular}{|c|c|c|c|c|}
\hline & & & & $\begin{array}{l}\text { satisfaction of customer needs and } \\
\text { engineering specifications. }\end{array}$ \\
\hline \multirow[b]{2}{*}{ d } & \multirow{3}{*}{$\begin{array}{l}\text { Multi- } \\
\text { Team }\end{array}$} & d. 1 & \begin{tabular}{|l|} 
Project \\
Planning And \\
Leadership \\
\end{tabular} & $\begin{array}{l}\text { Engage in project planning and tracking, } \\
\text { staying on track, assigning appropriate roles } \\
\text { based on skill set. }\end{array}$ \\
\hline & & d. 2 & Contribution & $\begin{array}{l}\text { Actively take on responsibility, meet } \\
\text { commitments to team mates and to project } \\
\text { quality, quantity, and timeliness of } \\
\text { deliverables. }\end{array}$ \\
\hline & & d.3 & Interaction & $\begin{array}{l}\text { Interact with team members in an appropriate } \\
\text { manner, encourage and consider ideas from } \\
\text { other team members. Apply strategies to } \\
\text { avoid and resolve conflict. }\end{array}$ \\
\hline \multirow[b]{2}{*}{$\mathrm{e}$} & \multirow[b]{2}{*}{$\begin{array}{l}\text { Prob. } \\
\text { Solv. }\end{array}$} & e. 1 & $\begin{array}{l}\text { Feasibility } \\
\text { Analysis }\end{array}$ & $\begin{array}{l}\text { Identify high risk design areas and perform } \\
\text { the appropriate feasibility analysis to } \\
\text { demonstrate the likely success of a proposed } \\
\text { design. }\end{array}$ \\
\hline & & e. 2 & Formulation & $\begin{array}{l}\text { Convert an ambiguous question into a } \\
\text { formal engineering problem statement, } \\
\text { identify the appropriate governing equations, } \\
\text { identify and apply assumptions, apply } \\
\text { appropriate mathematics to solve the } \\
\text { problem, verify and justify the answer (or } \\
\text { select the appropriate simulation tool, } \\
\text { identify and apply simulation parameters), } \\
\text { verify results and explain the effect of the } \\
\text { simplifying assumptions and/or simulation } \\
\text { parameters on the accuracy and validity of } \\
\text { results. }\end{array}$ \\
\hline \multirow[b]{2}{*}{$\mathrm{f}$} & \multirow[b]{2}{*}{$\begin{array}{l}\text { Prof. } \\
\text { Resp. }\end{array}$} & f.1 & Code & $\begin{array}{l}\text { Describe RIT's Academic Honesty Policy } \\
\text { and how it relates to specific academic } \\
\text { activities; identify a professional Code of } \\
\text { Ethics in a field of interest. }\end{array}$ \\
\hline & & f. 2 & $\begin{array}{l}\text { Professional } \\
\text { Responsibility }\end{array}$ & $\begin{array}{l}\text { Identify the ethical issues or professional } \\
\text { miscalculations associated with a historical } \\
\text { case study, describe the ramifications of key } \\
\text { engineering decisions, and the professional } \\
\text { and ethical responsibility of engineers in } \\
\text { each situation. }\end{array}$ \\
\hline \multirow{4}{*}{$\mathrm{g}$} & \multirow{4}{*}{$\begin{array}{l}\text { Com. } \\
\text { Effect. }\end{array}$} & g. 1 & $\begin{array}{l}\text { Solution } \\
\text { Format }\end{array}$ & $\begin{array}{l}\text { Clearly document the problem solving } \\
\text { method (FACIT) employed when presenting } \\
\text { solutions to engineering problems. }\end{array}$ \\
\hline & & g. 2 & Graphical & $\begin{array}{l}\text { Communicate graphically, diagrams, charts, } \\
\text { plots, schematics, sketches, FBDs }\end{array}$ \\
\hline & & g. 3 & $\begin{array}{l}\text { Technical } \\
\text { Report }\end{array}$ & $\begin{array}{l}\text { Write a technical report following a standard } \\
\text { format to document an engineering design, } \\
\text { test plan, or experimental, computational, } \\
\text { analytical or experimental results. }\end{array}$ \\
\hline & & g. 4 & Oral Pres & $\begin{array}{l}\text { Give an effective oral presentation on a } \\
\text { technical subject. }\end{array}$ \\
\hline \multirow{3}{*}{$\mathrm{h}$} & \multirow{3}{*}{$\begin{array}{l}\text { Broad } \\
\text { Edu. }\end{array}$} & h. 1 & Culture & $\begin{array}{l}\text { Describe and provide examples of ways in } \\
\text { which engineering, its artifacts, and practices } \\
\text { can affect culture and how culture influences } \\
\text { technological choices and practices. }\end{array}$ \\
\hline & & h. 2 & $\begin{array}{l}\text { Health And } \\
\text { Welfare }\end{array}$ & $\begin{array}{l}\text { Identify major economic, environmental or } \\
\text { health problems for which a novel } \\
\text { engineering solution has had or could have a } \\
\text { major impact on the health and welfare of } \\
\text { society. For example, historical case studies } \\
\text { (i.e. pace maker, Erie canal...) }\end{array}$ \\
\hline & & h.3 & Economic & $\begin{array}{l}\text { Apply basic engineering economics to } \\
\text { compare competing technology solutions. }\end{array}$ \\
\hline & $\begin{array}{l}\text { Life- } \\
\text { long } \\
\text { Learn. }\end{array}$ & i. 1 & Resources & $\begin{array}{l}\text { Independently identify, utilize and evaluate } \\
\text { publicly available resources (i.e. internet, } \\
\text { journals, patents, standards, tutorials), to }\end{array}$ \\
\hline
\end{tabular}




\begin{tabular}{|c|c|c|c|c|}
\hline & & & & gather and synthesize information. \\
\hline & & i. 2 & $\begin{array}{l}\text { Independent } \\
\text { Learning }\end{array}$ & $\begin{array}{l}\text { Demonstrate ability to actively and } \\
\text { independently pursue new learning } \\
\text { opportunities to successfully learn a new } \\
\text { skill. }\end{array}$ \\
\hline & & i. 3 & Career Path & $\begin{array}{l}\text { Identify possible career paths, describe the } \\
\text { education and licensure required for } \\
\text { continued growth and currency in the field, } \\
\text { and identify related professional societies } \\
\text { and explain the roles they play in the } \\
\text { industry. }\end{array}$ \\
\hline $\mathrm{j}$ & $\begin{array}{l}\text { Cont. } \\
\text { Issues }\end{array}$ & j.1 & $\begin{array}{l}\text { Current } \\
\text { Events }\end{array}$ & $\begin{array}{l}\text { Identify important contemporary regional, } \\
\text { national or global events in the market place } \\
\text { that may affect their career or engineering } \\
\text { solutions, e.g., changing regulations, medical } \\
\text { device tax, environmental regulations or } \\
\text { incentive, CAFE standards, privacy issues } \\
\text { related to UAVs, controversial science. }\end{array}$ \\
\hline & & .2 & \begin{tabular}{|l|} 
Emerging \\
Technologies \\
\end{tabular} & $\begin{array}{l}\text { Provide an overview of emerging } \\
\text { technologies within the field of engineering. }\end{array}$ \\
\hline & & k.1 & Design & $\begin{array}{l}\text { Use tools for (1) 3D CAD modeling (Solid } \\
\text { Works, Creo, Pro-E) and (2) } \\
\text { Fabrication/manufacturing- (3D printers, } \\
\text { CNC, other materials proc) }\end{array}$ \\
\hline & $\begin{array}{l}\text { Mod. } \\
\text { Tools }\end{array}$ & k.2 2 & Analysis & $\begin{array}{l}\text { Use tools for structural, thermo-fluids, } \\
\text { kinematic, kinetic analysis to (1) Solve ODE } \\
\text { (e.g Matlab, Excel, Visual Basic), (2) Solve } \\
\text { PDE (e.g Ansys, Comsol, Working Model), } \\
\text { and (3) Data and statistical (e.g. Minitab, } \\
\text { LabVIEW, Matlab) }\end{array}$ \\
\hline & & k.3 & Measurement & $\begin{array}{l}\text { Use tools for measurement (1) hardware (i.e. } \\
\text { transducers for temperature, pressure, flow, } \\
\text { deformation) (2) software (e.g. LabVIEW, } \\
\text { Matlab) }\end{array}$ \\
\hline & & k.4 & Controls & $\begin{array}{l}\text { Use tools for control (1) hardware (i.e. } \\
\text { controller boards, motors) and (2) software } \\
\text { (e.g. Simulink, LabVIEW, c++ or other } \\
\text { languages) }\end{array}$ \\
\hline
\end{tabular}

\section{INSTRUCTIONAL STRATEGY}

Instructional strategy describes the curricular content used to provide every student the opportunity to achieve the SOs. A holistic view of the ME program's instructional strategy is shown in Fig. 1. The ME program devised instructional levels as an innovative means to identify the type of instruction that is occurring in each course and its relative contribution to the SO. Specifically, Level 1 courses are expected to introduce a particular topic or skill as a prelude to a more in-depth treatment in a downstream course, but not necessarily provide sufficient depth for students to apply the knowledge. Level 2 courses are expected to provide foundation knowledge that will translate to long-term retention of key concepts. Level 3 courses are expected to provide students with the opportunity to realize long-term retention of specific outcomes. Level 4 courses are expected to provide students with a high-level experience of enhancing knowledge related to a specific outcome. Each level has a unique symbolic notation, starting with a quarter circle for Level 1 and ending with a full circle for Level 4.
The symbolic mapping shown in Table III provides a visual indicator for how each course contributes to each SO. These graphic symbols facilitate continuous improvement by illustrating opportunities where material and activities can be introduced earlier or reinforced later in the curriculum. The system makes clear where pre-requisite exposure of an outcome is relied upon in downstream courses. Furthermore, if the faculty have identified a particular course to address an outcome, the course could begin to address the outcome at level 1 and progress to level 2 as time and resources allow. A border around the symbol indicates that an assessment of PIs is collected and reported upon for this SO in this course.

TABLE III.

SYMBOLS MAPPING INSTRUCTIONAL STRATEGY, CURRICULAR ASSESSMENT POINTS AND ACHIEVEMENT.

\begin{tabular}{|c|l|c|c|}
\hline \multirow{2}{*}{ Instructional Level } & \multicolumn{2}{c|}{ Course Mapping } \\
\cline { 2 - 4 } & $\begin{array}{l}\text { Instruction } \\
\text { Level 1 } \\
\text { Enrichment activity to } \\
\text { expose students to new } \\
\text { material. }\end{array}$ & & Assessment \\
\hline Level 2 & $\begin{array}{l}\text { Students learn and apply } \\
\text { new material through formal } \\
\text { instruction. }\end{array}$ & & \\
\hline Level 3 & $\begin{array}{l}\text { Students apply and integrate } \\
\text { prerequisite material with } \\
\text { new material. }\end{array}$ & & \\
\hline Level 4 & $\begin{array}{l}\text { Students independently } \\
\text { learn, integrate and apply } \\
\text { new material. }\end{array}$ & & \\
\hline
\end{tabular}

\section{DATA SOURCES}

Data sources provide methods to gather evidence that SOs are achieved. Table IV lists the data sources used by the ME program to quantitatively assess achievement of SOs, assessed by both direct and indirect methods. Direct methods include assessment of student course work from the faculty perspective and performance on the job from the co-op employer's perspective. Indirect methods include an assessment of student co-op performance and overall preparation at the time of graduation, both from the student's perspective. Each of the eleven ME SOs is evaluated by at least one of these data sources. Each data source measures student achievement on a scale from to 1 to 5 , where 1 is poor, 3 is average and 5 is exemplary, using either a Direct Evaluation Rubric or an Indirect Evaluation rubric.

Specific details on the data sources, including types of student work and related courses, and co-op evaluation questions and data, are documented and stored in a shared version controlled repository, to which all faculty contribute and have access. In addition, the ME department maintains course binders and outcome binders that include examples of student work in support of each SO.

\section{A. Rubric for Direct Assessment}

$1^{\text {th }}$ LACCEI Annual International Conference: "Engineering Education Facing the Grand Challenges, What Are We Doing?" July 29-31, 2015, Santo Domingo, Dominican Republic 
Student work is assessed for each individual student, or student team and assigned an achievement level from 1 to 5 according to the rubric shown in Table V. Co-op employers evaluate student performance on the job using the same rubric, on a 1 to 5 scale, by answering questions that align with student outcomes. Each rating has a description for the employer to help gauge their response. However, faculty grading incorporates a wide range of rubrics and philosophies.

TABLE IV.

DATA SOURCES USED FOR QUANTITATIVE SO ASSESSMENT

\begin{tabular}{|c|l|l|l|l|}
\hline \multicolumn{3}{|c|}{ Type } & $\begin{array}{l}\text { Data } \\
\text { Collected }\end{array}$ & Responsible \\
\hline I & Student work & $\begin{array}{l}\text { Direct Course- } \\
\text { based }\end{array}$ & $\begin{array}{l}\text { Each } \\
\text { term }\end{array}$ & $\begin{array}{l}\text { Faculty teaching } \\
\text { course }\end{array}$ \\
\hline II & $\begin{array}{l}\text { Employer } \\
\text { Co-op } \\
\text { Evaluations }\end{array}$ & Direct & $\begin{array}{l}\text { Each } \\
\text { term }\end{array}$ & Co-op Office \\
\hline III & $\begin{array}{l}\text { Student } \\
\text { Co-op } \\
\text { Evaluations }\end{array}$ & Indirect & $\begin{array}{l}\text { Each } \\
\text { term }\end{array}$ & Co-op Office \\
\hline IV & $\begin{array}{l}\text { Graduating } \\
\text { exit surveys }\end{array}$ & Indirect & $\begin{array}{l}\text { Every } \\
\text { year }\end{array}$ & $\begin{array}{l}\text { ME Student } \\
\text { Services }\end{array}$ \\
\hline
\end{tabular}

TABLE V.

DIRECT EVALUATION RUBRIC FOR ASSESSMENT OF STUDENT PERFORMANCE

\begin{tabular}{|c|c|c|c|}
\hline \multirow{6}{*}{\begin{tabular}{l}
\multicolumn{1}{|c}{ Criteria } \\
Course Work \\
- Quiz \\
- Exam \\
multiple \\
choice \\
- Exam long \\
answer \\
- Homework \\
- Survey \\
- Lab \\
- Presentation \\
- Project \\
Co-op \\
Each outcome \\
is assessed by \\
employers \\
against \\
performance
\end{tabular}} & \multicolumn{2}{|c|}{ Achievement Level } & \multirow{2}{*}{$\begin{array}{l}\text { Description of Achievement } \\
\text { Student did not demonstrate } \\
\text { any level of achievement, even } \\
\text { after significant instruction. }\end{array}$} \\
\hline & 1 & Below standard & \\
\hline & 2 & $\begin{array}{l}\text { Progressing } \\
\text { toward } \\
\text { standards }\end{array}$ & $\begin{array}{l}\text { Student demonstrated only } \\
\text { partial achievement, or } \\
\text { required an unreasonable } \\
\text { amount of instruction }\end{array}$ \\
\hline & 3 & Meets standards & $\begin{array}{l}\text { Student demonstrated } \\
\text { achievement, and required no } \\
\text { more than a reasonable amount } \\
\text { of instruction. }\end{array}$ \\
\hline & 4 & $\begin{array}{l}\text { Exceeds } \\
\text { standards }\end{array}$ & $\begin{array}{l}\text { Student demonstrated } \\
\text { achievement, and required } \\
\text { little instruction of new } \\
\text { material and no instruction of } \\
\text { previous material. }\end{array}$ \\
\hline & 5 & Exemplary & $\begin{array}{l}\text { Student demonstrated } \\
\text { achievement with high } \\
\text { proficiency and independence. } \\
\text { A resource for others. }\end{array}$ \\
\hline
\end{tabular}

For example, one faculty member may feel a student who meets expectations, completes the work correctly should receive an "A" grade. Whereas another faculty member may feel only students who exceed expectations should receive an "A" grade, while those who meet expectations are average and should receive a "C" grade. For this reason, the assessment process in ME at RIT requires faculty to determine and document the grade cut-offs corresponding to each achievement level. This process yields an assessment of SOs independent of variations in grading rigor. As shown in Table
IV, scores on all samples of student work, labs, quizzes, reports, exams etc. are normalized to this global rubric and bucketed into 1 of 5 categories. This allows graded student work to be tallied in a standard fashion across the program to assess student outcomes.

\section{B. Rubric for Indirect Assessment}

Students evaluate their co-op performance, relative to each student, using the rubric shown in Table VI. The same rubric is used for graduating students to evaluate their overall preparation and achievement of each outcome.

TABLE VI.

INDIRECT EVALUATION RUBRIC FOR ASSESSMENT OF STUDENT PREPARATION

\begin{tabular}{|l|c|c|}
\hline \multicolumn{1}{|c|}{ Criteria } & $\begin{array}{c}\text { Achievement } \\
\text { Level }\end{array}$ & $\begin{array}{c}\text { Description of } \\
\text { Achievement }\end{array}$ \\
\hline Co-op & 1 & Minimal \\
\cline { 2 - 3 } $\begin{array}{l}\text { Each question is assessed against the } \\
\text { level of opportunity, academic } \\
\text { preparation and enhanced by co-op }\end{array}$ & 2 & ---- \\
\cline { 2 - 3 } \begin{tabular}{l} 
Graduating Exit Survey \\
\cline { 2 - 3 } $\begin{array}{l}\text { Each outcome is assessed against } \\
\text { academic preparation. }\end{array}$
\end{tabular} & 3 & Moderate \\
\cline { 2 - 3 } & 5 & Extensive \\
\hline
\end{tabular}

\section{Course Mapping for Collecting Student Work}

Courses contributing to outcomes assessment are shown in Fig. 1, using the symbolic notation described in Table IV. Every course contributing to a SO may not be used in outcomes assessment; targeted courses are chosen to provide meaningful data while maintaining a sustainable process. Courses contributing to the instructional strategy in support of the SO are marked with the appropriate instructional level symbol without a black border, whereas courses contributing assessment data have the added black border around the symbol.

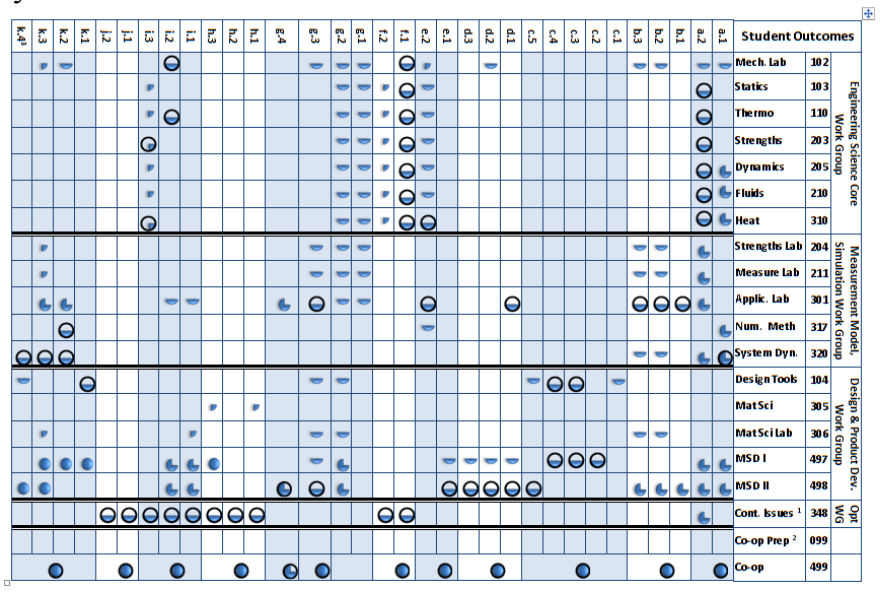

Fig. 1. Matrix of ME courses contributing to student outcomes and assessment thereof.

\section{ACHIEVEMENT OF STUDENT OUTCOMES}

\section{A. Reporting Student Performance}

13 $^{\text {th }}$ LACCEI Annual International Conference: "Engineering Education Facing the Grand Challenges, What Are We Doing?" July 29-31, 2015, Santo Domingo, Dominican Republic 
Overall student performance is reported by SO in a stacked bar graph in which each section represents the percent for each achievement level, 1 (below expectations) to 5 (exceeds expectations). A set of four stacked bar graphs is reported for each $\mathrm{SO}$, one stacked bar graph for each data source listed in Table III. An example plot for assessment of student work, "Data Source I" is shown in Fig. 2. In Fig. 2, for example, in academic term " 211, , $31 \%$ of the students rated exemplary, $22 \%$ rated exceeds, and $10 \%$ rated meets. Altogether, $63 \%$ of the students met or exceeded the standard. Each instance of student work is weighted equally, and cumulative values are reported for given academic year. Data is stored in a pivot table so faculty are able to sort the data and evaluate performance as function of performance indicator, course, type of student work (exam question, homework, project, etc.), academic term, or any combination of factors. This allows faculty to better understand the data behind the overall student performance value and make necessary changes to the assessment or instructional strategy at a finer level.

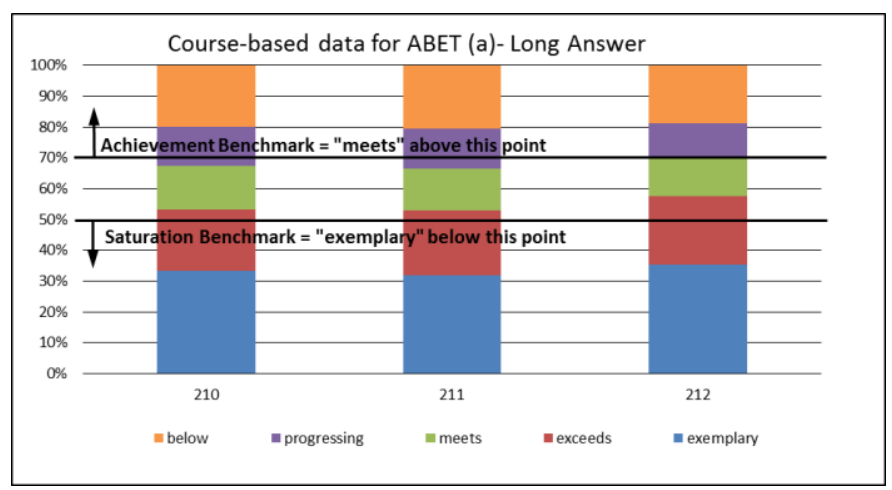

Fig. 2. Example plots for longitudinal direct assessment of SOs by student work. Student work was rated 1 to 5 . 1=below, $2=$ progressing, $3=$ meets,

$4=$ exceeds, $5=$ exemplary. Data was compiled over six courses by academic years 2010-11, 2011-12, 2012-13

An example plot for assessment of Co-op employer evaluations, "Data Source II", is shown in Fig. 3. Using a global rubric for direct assessment of SOs by various data sources allows faculty to evaluate not only achievement but also the relative impact of different data sources on the assessment process.

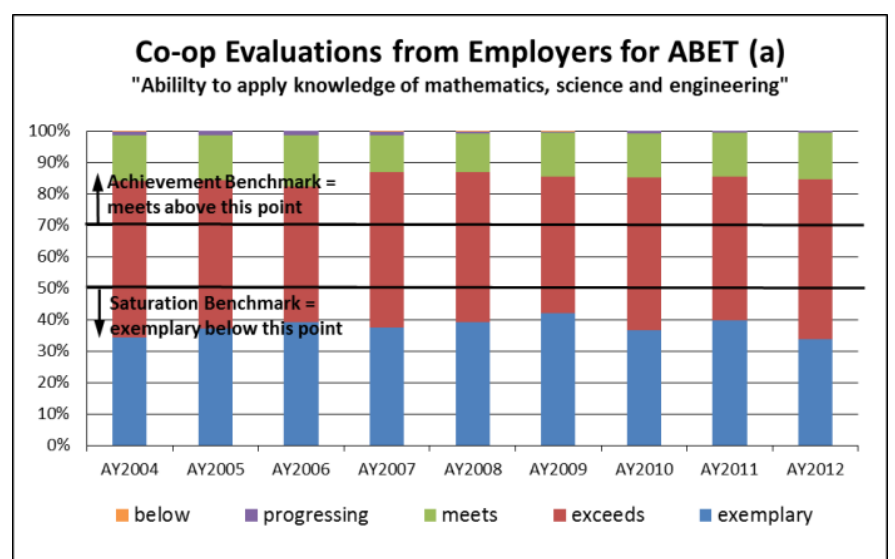

Fig. 3. Example plots for longitudinal direct assessment of SOs by co-op employer data.

\section{B. Evaluating Performance Against Benchmarks}

Student performance for each outcome, ABET (a) through (k) and each data source (Table III) is evaluated against the achievement benchmarks shown in Table VII. A SO meets the benchmark if $70 \%$ of the data indicate an achievement level of 3,4 or 5 out of 5 (less than $30 \%$ of the data were rated 2 or 1 out of 5). For example in Fig. 2, 63\% of the students achieved a $3 / 5$ or above, which falls below the benchmark of $70 \%$. A $\mathrm{SO}$ is considered saturated, meaning there is little room for improvement, if $50 \%$ of the data collected indicates an achievement level of 5/5. A category for "no opportunity to observe" was included as a means for faculty to track when data sources were unavailable. Student performance is reported using the symbolic notation given in Table II to indicate the extent to which individual performance indicators met the benchmarks. Green and red symbols are used to indicate that the outcome was met or not met, respectively. Purple is used to indicate that the benchmark was saturated. Fig. 2 and 3 show an example of how the benchmark comparisons are made. In each Fig. an achievement benchmark is noted as well as a saturation benchmark. Fig. 2 shows that the number of students who meet or exceeds expectations falls below the benchmark, whereas Fig. 3 from the co-op employers indicate that the benchmark was met. In both figures, the saturation benchmark was met because the percent of students achieving $5 / 5$ falls below the $50 \%$ mark. The discrepancy between the two plots sparked faculty discussion around the appropriateness of data sources, the failure of students to meet the benchmark with course work but exceed the benchmark while on co-op. These plots provide a tool that feeds the continuous improvement process. 
TABLE VII.

BENCHMARKS FOR ACHIEVEMENT

\begin{tabular}{|r|c|c|c|c|c|c|}
\hline Achievement Level & 1 & 2 & 3 & 4 & 5 & $\begin{array}{c}\text { No opportunity } \\
\text { to observe }\end{array}$ \\
\hline $\begin{array}{r}\text { Achievement } \\
\text { Benchmark }\end{array}$ & $<30 \%$ & \multicolumn{5}{|c|}{$\geq 70 \%$} \\
\hline $\begin{array}{r}\text { Saturation } \\
\text { Benchmark }\end{array}$ & \multicolumn{3}{|c|}{$\geq 50 \%$} & $\leq 50 \%$ & $0 \%$ \\
\hline
\end{tabular}

\section{CONTINUOUS IMPROVEMENT PROCESS}

The ME program at RIT utilizes a three-point continuous improvement process which involves a holistic evaluation of (1) the extent to which student outcomes are achieved, (2) the appropriateness of the instructional strategy intended to produce the desired outcomes, and (3) the appropriateness of the data sources used as indicators of achievement. The continuous improvement process is illustrated in Fig. 4.

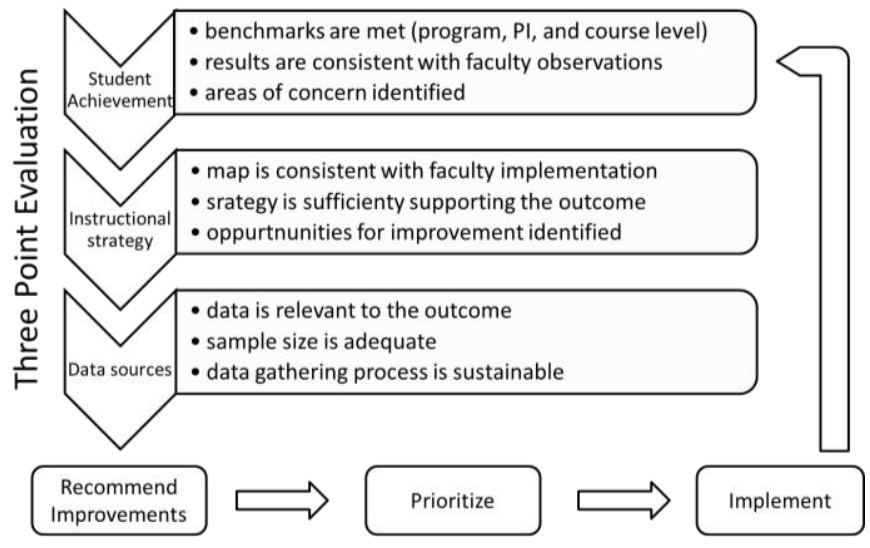

Fig. 4. RIT ME program's three point continuous improvement process

Although benchmark comparison is an important part of the process, it is used primarily as a point of reference. Whether or not a benchmark is met does not automatically imply that an action must be taken. Effective benchmark comparison requires the expertise and perspective of the faculty to determine the appropriate next steps.

For example, faculty consider if the results accurately reflect their observations and perceptions. If any discrepancy is found, then faculty may suggest revisions to the assessment strategy in either the short term or long term. If the data seems to reflect and confirm faculty perceptions, faculty will then discuss areas for improvement either in the instructional strategy, mapping of content to outcomes or the assessment plan. If any SO or PI is not achieved, faculty may consider rearranging course content or delivery methods to improve student performance.

It is possible that the four data sources will indicate different levels of achievement. For example, the Co-op employer data may indicate that an SO benchmark was met while the student work may indicate that the SO benchmark was not met. In such cases a holistic qualitative assessment is used to decide upon appropriate improvement actions.

If achievement of any PI is saturated, faculty may consider increasing the rigor of the course by adding new material, and/or by including higher Bloom's level activities or elevating the course to a higher instructional strategy level.

Ultimately, faculty devise a list of recommendations which are documented in the midterm reports along with the supporting assessment data and benchmark comparisons. Improvement action plans are incorporated into work group charges when deemed appropriate.

\section{REFERENCES}

[1] Abet, 2014, "Criteria for Accrediting Engineering Programs," ABET Engineering Accreditation Commission, Baltimore, MD.

[2] Lending, D., Mathieu, R. G., and Acm, 2010, "Workforce Preparation and Abet Assessment," Sigmis Cpr '10: Proceedings of the 2010 Acm Sigmis Computer Personnel Research Conference, pp. 136-141.

[3] Gnanapragasam, N., 2008, "Industrially Sponsored Senior Capstone Experience: Program Implementation and Assessment," Journal of Professional Issues in Engineering Education and Practice, 134(3), pp. 257-262.

[4] Yue, K.-B., 2007, "Effective Course-Based Learning Outcome Assessment for Abet Accreditation of Computing Programs," Journal of Computing Sciences in Colleges, 22(4), pp. 252-259.

[5] Burge, L. L., and Leach, R. J., 2010, "An Advanced Assessment Tool and Process," Proc. Proceedings of the 41 st ACM technical symposium on Computer science education, pp. 451-454.

[6] Mckenzie, L. J., Trevisan, M. S., Davis, D. C., and Beyerlein, S. W., 2004, "Capstone Design Courses and Assessment: A National Study," Proc. Proceedings of the 2004 American Society of Engineering Education Annual Conference \& Exposition, pp. 1-14.

[7] Meyer, D. G., 2005, "Capstone Design Outcome Assessment: Instruments for Quantitative Evaluation," Proc. FRONTIERS IN EDUCATION CONFERENCE, 35, pp. F4D. [8] Shuman, L. J., Besterfield-Sacre, M., and Mcgourty, J., 2005, "The Abet "Professional Skills"-Can They Be Taught? Can They Be Assessed?," Journal of Engineering Education, 94(1), pp. 41-55.

[9] Rainsbury, E., Hodges, D., Sutherland, J., and Barrow, M., 1998, "Academic, Employer and Student Collaborative Assessment in a Work-Based Cooperative Education Course," 
Assessment \& Evaluation in Higher Education, 23(3), pp. 313-

324.

[10] Hensel, E., and Robinson, R., 2014, "Direct Assessment of Student Learning Outcomes by Analysis of Performance Evaluation of Student Employees," Guayaquil, Ecuador. [11] Spurlin, J. E., Rajala, S. A., and Lavelle, J. P., 2008, Designing Better Engineering Education through Assessment : A Practical Resource for Faculty and Department Chairs on Using Assessment and Abet Criteria to Improve Student Learning, Stylus Pub., Sterling, Va.

[12] Hensel, E., Ghosh, A., and Asme, 2010, A Case Study on Course-Based Outcomes Assessment to Enhance Student Learning and Course Delivery in the Engineering Sciences Core Curriculum. 